\title{
Exploring current arts practice in kindergartens and preparatory classrooms
}

\author{
Susanne Garvis \\ Griffith University
}

THE ARTS ARE AN IMPORTANT AREA of development for young children in their early years. By engaging with arts activities, young children are able to use their senses to explore the world. This paper reports on current arts practice in two kindergartens and two preparatory classrooms in Queensland, Australia. All sites are located in neighbouring suburbs. Findings reveal children in kindergarten are exposed to an arts-rich environment. In preparatory classrooms, few examples of arts activities could be observed, with children mostly accessing only one weekly 30-minute music lesson with a specialist teacher. Arts practice in classrooms was related to each teacher's philosophy of arts education, and the amount of arts education exposure they received during teacher education. Findings bring to the surface the tensions between kindergarten and preparatory education, and highlight the importance of adequate arts education in early childhood teacher education programs.

\section{Introduction}

The arts are important in early childhood education. They are a powerful form of communication, especially when words are either inadequate or unavailable (Wright, 2003a). They are considered essential for helping children explore the world through their senses; children can engage in concepts of making and creating. The essence of young children's meaningmaking is a synthesis of thought, body and emotion (Wright, 2003a, 2003b). Children's rich and integrated creations include many signs, words, graphic devices, onomatopoeia, writing, and gestures/postures which stand for or represent other things (Wright, 2007). The significance of the arts is also recognised in curriculum documents for kindergarten and preparatory classrooms in Queensland, Australia. More recently, it has been recognised as an important area of learning in the Australian National Curriculum.

This study explores current arts practice in two kindergartens (children aged three-and-a-half) and preparatory classrooms (children aged four-and-ahalf) in Queensland. Early childhood teacher beliefs about the philosophy and valuing of arts education were also explored. Findings suggest that when kindergarten children are exposed to an art-rich environment, it encourages domain-intrinsic knowledge.
In the preparatory classrooms, a more formal schooling structure was employed, with little time devoted to the arts. Children in preparatory classrooms had access to 30 minutes a week of music education with a specialist music teacher. The majority of generalist classroom time was spent on formal teaching of literacy and numeracy. Findings reveal the tensions between kindergartens and preparatory classrooms in Queensland, and also show that teacher philosophy about arts education may be based on provision for it in early childhood teacher education.

\section{Literature}

There has been increasing recognition of the importance of the early years for children's learning at both national and international levels (Shonkoff \& Phillips, 2000). Recent reports from the Organisation for Economic Cooperation and Development (OECD) (2006) outline the commitments of 20 OECD countries (including Australia) to developing early childhood policy and to assessing quality within early childhood services. Policy-makers are also aware of the importance of educational investments in the early years that yield the highest return for each dollar invested (Rolnick \& Gruenwald, 2003). Heckman (cited in Vimpani, 2005) notes that: 
People who participate in enriched early childhood programs are more likely to complete school and much less likely to require welfare benefits, become teen parents, or participate in criminal activities.

Early years education and care prior to formal schooling (licensed early years settings) is a key priority area of the Queensland and federal governments. In October 2008, the Queensland Government announced the plan Toward Q2 Tomorrow's Queensland: Delivering World Class Education-Starting Early to ensure all Queensland children have access to a kindergarten program by 2014. This is part of the Council of Australian Governments agreement for universal access for all children to quality early childhood education and care prior to formal schooling. In Queensland this initiative includes the creation of an extra 240 kindergarten services, with 108 new services expected to open in 2012. The kindergarten services are scheduled to open in areas of need to cater for kindy-aged children not currently accessing centre-based early childhood education and care services (about 12,000 children) (Queensland Government, 2008).

Eisner (2002) argues that, through active engagement with arts experiences, children can develop their senses and their imagination:

The senses provide the material for the creation of consciousness, and we, in turn, use the content of consciousness and the sensory potential of various materials to mediate, transform, and transport our consciousness into worlds beyond ourselves (pp.17-18).

The arts are an important learning area for young children and are included in many education programs, allowing meaning-making and communication. According to Wright (2007, p. 37), 'young children's meaning-making is a multifaceted, complex experience, where thought, body and emotion unite'. Wright (2007, p. 37) provides an example of children's drawing where:

... the assembled signs can include graphically produced images (e.g. people, objects), which might also include written letters or words, numbers, symbols (e.g. flags) and graphic devices (e.g. 'whoosh' lines behind a car). In addition, this graphic content may be accompanied by children's sounds (e.g. expressive vocalisation) and imitative gestures to enhance the meaning. Hence, when children draw, they construct and interpret a range of verbal and non-verbal signs with reference to the conventions associated with this medium of communication.

Engaging children in the creative arts can allow them to communicate in potentially profound ways (Eisner, 2002). As Russell-Bowie (2009, p. 5) points out 'because the arts can embody and communicate emotions, ideas, beliefs and values, they can convey meaning through aesthetic forms and symbols and evoke emotive responses to life with or without words'.

Communication between teacher and child is also important in arts engagement. Early interactive dialogue vocalisation between infant and caregiver is considered important for supporting communicative and caring acts (Trevarthen \& Malloch, 2000). Researchers argue that the blend of music and language elements supports early acquisition of these skills (Papousek, 1996). It is considered the foundation to infant identity (Trevarthen, 2002), and is implicated in the development of the arts in human thought and activity (Dissanayake, 2000, 2001). Barrett (2006, p. 207) further argues that 'children's creative thought and activity arise from early adult-infant interactions where the foundations for language, music and emotional, social and cultural development are laid down'.

Many Australian documents currently acknowledge the importance of arts in education. The expectation of arts education was made public when the Australian Ministerial Council on Education Employment, Training and Youth Affairs (MCEETYA) released a statement entitled the National Education and the Arts Statement (2005). Building on from the Adelaide Declaration on National Goals for Schooling in the Twenty-First Century (1999), this statement was designed to foster a culture of creativity and innovation in Australian schools. It acknowledged that an education rich in the creative arts maximises opportunities for learners to engage with innovative thinkers and learners, emphasising not only creativity and innovation, but also the values of broad cultural understandings and social harmony that the arts can engender. This is similar to UNESCO's Road Map for Arts Education (2006), with arts considered a necessity for skill development in the twenty-first century, allowing nations to develop the human resources necessary to tap their cultural capital.

The Australian National Education and Arts Statement (2005) acknowledged that arts experiences enhanced all phases of schooling. All students, irrespective of their location, socio-economic status or ability should have equal opportunities to participate in arts-rich schooling (MCEETYA, 2005). School-based arts experiences should be diverse, based on models of effective practice, and embedded from the early years through to graduation in order to unlock the creative potential of young people (MCEETYA, 2005). The statement acknowledges the need to foster teachers' skills and knowledge.

In 2009, the document Belonging, Being and Becoming-The Early Years Learning Framework for Australia (COAG, 2009) was released for all children from birth to five years. The document mentions the arts as an important area for children, raising awareness of the arts in education nationally for the early years. 


\section{Beliefs about arts and young children}

McArdle (2001) suggests many taboos against teaching exist when it comes to art in early childhood education. There is a common belief that teachers should not interfere with the art-making of young children (Richards, 2007). The belief suggests children are best left unhindered in their arts development. Richards (2007) challenges this view, arguing that learning in the arts is a social, cultural and historical act. McArdle and Wong (2010) also note it is not enough to observe children from a distance and plan learning programs based on assumptions about what they are doing and thinking. Pramling Samuelsson et al. (2009, p. 133) suggest 'children are creative and masters of play, but in order to become aware of distinctions, variation and invariance of the phenomena of the arts, children must be challenged by the teacher in order to clarify and develop their thought'. Accordingly, the goal is to help children develop domain-intrinsic knowledge about the arts, rather than merely using the arts as a means for developing art-extrinsic knowing (Pramling Samuelsson et al., 2009). Domain-intrinsic knowledge can be defined as specific knowledge about each of the arts forms. For example, in music it could include beat, rhythm and pitch. In the Shape of the Australian Curriculum: The Arts (ACARA, 2011) the arts knowledge development for grade foundation (first year of formal schooling) to Grade 2 students has been listed:

- In dance, 'students will gain a basic understanding of the elements of dance and improvise playfully with the body to explore and control movement. They will communicate through the body to make and share performances with their peers. They will experience connections to other Arts subjects, especially music to dance. Students will view, discuss and listen to opinions about their own and others' dances' $(2011$, p. 8).

- In drama, 'students will begin to learn and use some of the elements of drama. They will explore and learn about role, relationships and narrative through dramatic play, role-play, improvisation and process drama as they explore and depict stories involving causes and consequences. They will experiment with objects, puppets and images. They will engage in informal and often spontaneous performance to classroom and in-house audiences, using their own language and movement, and sometimes simple props and costumes. Students will reflect on their own work and respond to theatre' (2011, p. 10).
- In media arts, 'students will experiment creatively with a range of communications technologies and digital materials. They will begin to understand and make simple stories using written text, images and sound. They will view and listen to printed, visual and moving image media and respond with relevant actions, gestures, comments and/or questions. Students will understand that stories are made by different people and groups for different purposes' (2011, p. 12).

- In music, 'students will learn about and participate in the different roles of composer, performer and audience member. They will explore and experiment with voice, instruments and sound to create their own music. They will sing, play instruments and move to a range of music. They will develop a repertoire of chants, songs, rhythms, rhymes and melodies. They will invent and explore ways of recording musical thinking through symbols. Students will begin to use music terminology. They will listen and respond to a range of musical works and develop their aural skills. They will learn to respond and comment on their own music making and that of others' (2011, p. 14).

- In visual arts, 'students will learn through making and responding to visual art works. They use a range of equipment, materials, media and technologies to make art, craft and design works that communicate their ideas, feelings and observations of personal and community experiences. In so doing they will begin to develop skills and to learn about processes. Students will look at artworks and talk about what they see, beginning to use the language of visual arts. They will start to recognise different purposes and contexts of art, thus starting to discriminate and engage as audiences. They will start to understand that works of art, artists and designers have a place in their communities, and that specific works of art tell narratives about themselves and about their own and other cultures' (2011, p. 16).

In the year before formal schooling, children attending kindergarten can also be working towards these goals. In the Early Years Learning Framework (COAG, 2009), the arts are mentioned as an important tool for children to communicate and engage in learning. For example, the arts are used to enable children to demonstrate Outcome 4 (children are confident and involved learners) and Outcome 5 (children are effective communicators). Children 'used the creative arts such as drawing, painting, sculpture, drama, dance, movement, music and story telling to express ideas and make meaning' (2009, p. 42). 
In the Early Years Learning Framework, the arts are also considered a part of literacy. According to the Framework (2009, p. 38), literacy also 'incorporates a range of modes of communication including music, movement, dance, story telling, visual arts, media and drama, as well as talking, listening, viewing, reading and writing'. Examples are given of how they align with outcomes. Outcome 4 (that children are confident and involved learners) has an example of children being able to 'model mathematical and scientific language and language associated with the arts' (p. 35).

\section{Teacher beliefs}

The construct of teacher self-efficacy beliefs emphasise that people can exercise influence over what they do (Bandura, 2006). Self-efficacy is defined as 'beliefs in one's capabilities to organize and execute the courses of action required to produce given attainments' (Bandura, 1997, p. 3). Efficacy beliefs are believed to predict the outcomes people expect (Bandura, 1997), leading to the assumption that teachers' beliefs regarding their own capabilities as teachers have a powerful influence on their effectiveness with students. It is for this reason that Woolfolk (see Shaughnessy, 2004) suggests that teachers who seek to help students increase their academic and self-efficacy should first attend to the sources underlying their own teacher beliefs. Previous research suggests that self-efficacy beliefs for arts education in new middle years teachers (Garvis, 2010) and early childhood teachers (Garvis \& Pendergast, 2011) is low. Little is known, however, about how these beliefs are exhibited by teachers in the classroom, or their origins in the teachers themselves.

\section{Focus of research}

Given the recent changes with early childhood reform, little is known about pedagogical practices with the arts in the early years. This study explores current arts practice in kindergarten and preparatory classrooms in Queensland, and the beliefs of the kindergarten and preparatory teachers to reveal the value they place on the arts for young children. The specific research questions are:

1) How are the arts currently used in kindergarten and preparatory classrooms in Queensland, Australia?

2) What beliefs do early years teachers have about the teaching of the arts in early years classrooms?

\section{Context of study}

This study was conducted in two kindergartens and two preparatory classrooms in South East Queensland. All classrooms were located within two suburbs of each other. Each of the four teachers selected was registered and had completed a Bachelor degree. The two teachers in kindergarten each had over 20 years of experience. One teacher in the preparatory classroom had 12 years of experience while the other was a recent graduate.

In Queensland, kindergarten is for children aged three-and-a-half years. While it is not compulsory, the universal education agreement (COAG, 2009) acknowledges that, by 2014, all children (of kindergarten age) across Australia will have access to 15 hours of a quality early childhood education program with a qualified teacher.

Preparatory is the first year of formal schooling in Queensland (children are aged four-and-a-half, turning five). It is known as the year before school. Preparatory is a five-days-a-week full-time program from 9am to $3 \mathrm{pm}$. With the introduction of the Australian National Curriculum, the preparatory year (also known as foundation year) is considered the first year of formalised learning, with current official subjects being maths, English, science, history, arts, languages and geography. Other curriculum areas are currently being explored to be included.

\section{Method}

My approach to research is one where knowledge is considered to be a subjective 'human construction' (Hatch, 2002, p. 13). As an interpretivist researcher, I understand that 'knowledge is socially constructed' (Denzin \& Lincoln, 2000, p. 8).

A qualitative method was used for this study, which collected interview data, field notes and observations from four different sites in Queensland. The three points of data allowed for triangulation.

Early years teachers engaged in a 30-minute faceto-face, semi-structured interview to discuss their philosophy of arts education and the role of the arts in children's learning. As Vygotsky (cited in Seidman, 1991, p. 12) says, 'the very process of putting experience into language is a meaning-making process'. Interviews are an established method of gathering data in social sciences (Fontana \& Fey, 2000; Gubrium \& Holstein, 2002). Question design was based on the model of question-answer behaviour explored by Foddy (1993), providing important principles to ensure answers were interpretable and comparable. An example of a question is: 
- How would you describe your philosophy of arts education?

Questions were sent to the early years teachers prior to the interview. After the interview, data was transcribed from the recorded interviews, and sent to the participants for checking.

Field notes were taken at each of the sites over a period of one day to observe all elements of arts practice. The researcher sat in the back of the classroom, observing the environment and documenting the provision of arts in the classroom. To aid in remembering field notes, photos were also taken around the room. Field notes were crosschecked with the teacher in each of the classrooms.

Content analysis was used to show key themes that were common across beginning teachers' beliefs and perceived experiences. Content analysis is 'a research technique for making replicable and valid inferences from texts to the context of their use' (Krippendorf, 2004, p. 18). An adapted version of Cavana, Delahaye and Sekaran's (2003, p. 171) 15 stages of content analysis (based within the constant comparative method) was used to identify key themes and meanings. This process allows newly identified themes to be compared with previously identified themes to ensure that the new theme adds more understanding about the phenomenon under investigation. Coding for manifest content (Wallen \& Fraenkel, 2001) was used, acknowledging what was directly written.

Three major themes emerged across the four sites: (1) arts were part of the daily routine in kindergartens but not in preparatory classrooms; (2) teachers' philosophy about the arts shaped classroom practice; and (3) teachers' prior experiences in teacher education shaped arts practice.

\section{Findings}

\section{Arts were part of the daily routine in kindergartens but not in preparatory classrooms}

The first theme to emerge was the difference of provision for the arts in early years education. In kindergarten classrooms, arts featured heavily alongside the play-based curriculum. The arts featured as an individual learning activity. During observations, music was used for many introductions, transitions and routines in the classroom. During activity time, dramatic play and creating objects with craft were encouraged. Children also investigated the mixing of colours, painting, clay and playdough, and were continually emerged in sensory-based activities.
An example below is of a three-year old's re-creation of a giraffe. The class was studying zoo animals and the boy had a fascination with learning more about the giraffe. He initially had problems with the giraffe's feet and used his problem-solving skills to work out ways to make the giraffe stand straight.

Figure 1: Giraffe

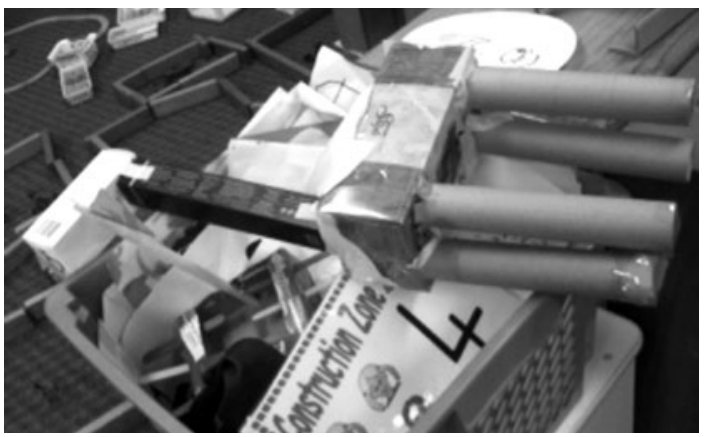

The teachers had focused time for music and art where they intended to teach domain-intrinsic knowledge about the arts. Similar focused teaching and learning segments were used for literacy and numeracy. In the case of music, students were learning domainintrinsic knowledge about low sounds, high sounds, beat and rhythm. In art, children were learning about different shapes and textures.

The kindergarten teachers cautioned about children entering into preparatory classrooms that did not embrace the arts in learning:

In a play-based curriculum it is easier to embed arts practices throughout the day with the children being able to guide the decision making and amount of engagement they have. I fear that preparatory will not keep its intended play-base and will inhibit the opportunities for rich engagement with as many of the Arts as there should be. Arts in education helps to meet the various learning styles of all children and should be something that is embedded in daily practice not something 'you do if time permits' (Kindergarten Teacher 2)

In both preparatory classrooms, arts did not feature as an important area of learning for children. Most of the morning involved children sitting at desks or in group work situations, studying literacy and numeracy. Little time was devoted to engaging children in literacy and numeracy that engaged the arts (such as singing a counting game). Limited arts integration also occurred with other key learning areas. Limited music was used for transitions such as traditional greeting songs at the start of the day and transitions songs to morning tea and lunch. 
Children in both preparatory classrooms had access to 30 minutes of music education a week with a music specialist outside of their classroom. Children were engaged in minor 'art craft' when creating cards for Father's Day.

In talking to both preparatory teachers, both raised concerns about the loss of play-based learning in their school. Both suggested that, with the National Assessment Plan for Literacy and Numeracy (NAPLAN) and the Australian National Curriculum, formalised teaching was needed to make sure the young children would be ready for the test requirements in three years' time. In NAPLAN, every year, children in Years 3, 5, 7 and 9 sit standardised national tests in reading, writing, language conventions and numeracy. School results are published online for the public. The Australian National Curriculum is a formal curriculum for all Australian children from foundation year (also known as preparatory or kindergarten in some states) to Year 12. As one preparatory teacher commented:

I know I should be engaging with the arts but it is not valued by the education system, the principal or even the parents. Everyone wants their child to read and write as quick as possible (Preparatory Teacher 1).

\section{Teachers' philosophy about the arts shaped classroom practice}

In the interviews and observations it became evident that teachers' arts practice was shaped by their teaching philosophy, the way they viewed child development, children's learning and their own teaching.

The kindergarten teachers saw the arts as an important area of development for young children. The arts were considered just as important as literacy and numeracy and needed to be taught as an individual subject. They could also be used as a medium to teach literacy and numeracy, and were considered valuable for allowing children multiple ways of understanding and representing their world. The kindergarten teachers also discussed their role of helping to support creativity through facilitating suitable learning environments that promote the arts, teaching the skills associated with different arts forms and helping children to transfer their skills to other learning areas. This can be summed up in the words of one of the kindergarten teachers:

I see arts as important to ensure that children have multiple ways of understanding their world, and to be able to express themselves in 'many languages'. Creativity, particularly expressed in 'arts' involves high level thinking skills which should be accessible to all children. Our role as EC educators is to:

- Value the individual and open-ended responses of creative endeavours.

- Facilitate environments that promote arts (time, space, resources).

- Teach skills.

- Support children to transfer knowledge, skills and dispositions learnt through arts practice to other areas of their lives.

(Kindergarten Teacher 1).

The preparatory teachers were also asked to comment on their philosophy of arts education. Interestingly, both teachers admitted they did not feel capable of teaching the arts. While they were committed to a play-based curriculum, they did not consider the arts to be a foundation for it.

While the kindergarten teachers used words of 'support', 'open-ended' and 'facilitating', the preparatory teachers used words of 'teach', 'benchmarks' and 'assessment'. Preparatory teachers suggested their teaching philosophy was to 'teach the children' through many focused teaching and learning segments. Both preparatory teachers were concerned that their students had to reach 'benchmarks' by the end of the year that could be assessed through exams. Both admitted they did not know how to 'assess the arts'.

\section{Teachers' prior experiences in teacher education shaped arts practice}

Much of the teachers' experience appears to extend from prior experiences in early childhood teacher education. Both kindergarten teachers had entered teachers' college in the 1970s. The first preparatory teacher had entered teacher education in the 1990s, and the other preparatory teacher was a recent graduate. From talking to the teachers, it appeared that the provision for arts in teacher education had changed significantly. This can be demonstrated in the two examples below.

A kindergarten teacher recounted her experience as:

In the era in which I went to kindergarten teachers' college (mid 1970s) early childhood education was very much seen as responding to middle class values, in which the arts were highly valued, particularly for young children. I think they were seen as 'suitable' activities to engage little minds before children were able to read and write. Therefore I did quite a few 'arts' based subjects at college including visual arts, music subjects each semester which included 'singing', orchestra (hilarious), piano, guitar, appreciation of musical styles (Kindergarten Teacher 1). 
The preparatory teacher commented:

I didn't really get a lot of arts education in teacher education. It was more towards literacy and numeracy. We did one subject in first year of our four year degree. We had class for two hours a week - so about 20 hours in total. We learnt about the theory of the arts but we didn't actually experience the arts (Preparatory Teacher 2).

The provision of arts in teacher education appears to influence the philosophy of teachers in the classrooms. Both kindergarten teachers had experienced the arts each semester, while the preparatory teachers had few experiences with the arts in teacher education. In their arts practice, both kindergarten teachers implemented more arts activities in their classroom than did the preparatory teachers.

\section{Discussion and conclusion}

This study has shown insight to how the arts are being using in Queensland early years classrooms and the beliefs that early years teachers have about the arts. A key finding in this study has been that the provision of arts in teacher education appears to influence the philosophy of teachers in classrooms. If teachers have low exposure to arts during teacher education, they have limited belief about the importance of arts experiences for young children and the role of the arts in other learning areas such as literacy. Both kindergarten teachers had regular engagement with the arts every semester during their teacher education, while the two preparatory teachers had only a semester of arts training at university. Previous work exploring primary school teachers' level of teacher education suggests that negative or limited arts experience decreases confidence (Garvis \& Pendergast, 2010). The same finding also appears true of the four teachers in this study. Adequate time in teacher education is needed for early years teachers to develop confidence for embedding the arts in their future classrooms.

The philosophy of arts held by the kindergarten teachers appeared different from that of the preparatory teachers. The kindergarten teachers saw the arts as highly valuable and an important way for children to explore and make meaning of their environment. The arts were also seen as a means of literacy and communication, with the kindergarten teachers' beliefs aligning with the Early Years Learning Framework (COAG, 2009). The preparatory teachers held a philosophy linked to traditional notions of teaching. The arts were regarded as a subject that was rarely integrated with other subjects, and not considered a part of literacy as in the Early Years Learning Framework (COAG, 2009). While the preparatory teachers admitted they did not feel comfortable teaching the arts, they were supportive of play-based curriculum. This is interesting, considering that play is considered the foundation for arts in early childhood. As Eisner (1990, p. 55) points out:

Both play and art have much in common. Both engage imagination, both require reflection, both profit from skill, both seek to generate new forms of experiences, both lead to invention, and both are marginalized in the priorities of American education. In my view both children and their culture which they live would be better served if art and play had a more prominent place in our schools.

More larger-scale research is necessary to determine arts practice in kindergartens and preparatory classrooms throughout Australia. Further investigation could explore the development of domain-intrinsic knowledge over time. More research is also needed into the effects of including more arts practice into early years teacher education. We know that arts education is important for young children's learning, and greater measures are necessary to improve arts practices in early years classrooms throughout Australia, both before the formal years of schooling and within the formal years of schooing.

\section{References}

Australian Curriculum, Assessment and Reporting Authority. (ACARA) (2011). Shape of the Australian Curriculum: The Arts. Retrieved 30 January, 2012 from http://www.acara.edu. au/verve/_resources/Shape_of_the_Australian_Curriculum_ The_Arts_-_Compressed.pdf.

Barrett, M.S. (2006). Inventing songs, inventing worlds: The "genesis" of creative thought and activity in young children's lives. International Journal of Early Years Education, 14(3), 201-20.

Cavana, R. Y., Delahaye, B. L. \& Sekaran, U. (2001). Applied business research: Qualitative and quantitative methods. Brisbane, Queensland: John Wiley and Sons.

Council of Australian Governments (COAG) (2009). Belonging, being and becoming-The Early Years Learning Framework for Australia. Retrieved 2 September 2011 from http://www.deewr.gov.au/Earlychildhood/Policy_Agenda/ Quality/Documents/Final\%20EYLF\%20Framework\%20 Report\%20-\%20WEB.pdf

Denzin, N. K. \& Lincoln, Y. S. (Eds). (2000). Handbook of qualitative research (2nd ed.). Thousand Oaks, CA: Sage.

Dissanayake, E. (2000). Art and Intimacy: How the Arts Began. Seattle: University of Washington Press.

Dissanayake, E. (2001b) 'Becoming homo aestheticus: sources of aesthetic imagination in mother-infant interactions'. SubStance, 94/95, 85-103.

Eisner, E. (1990). The role of art and play in children's cognitive development. In E. Klugman and S. Smilansky (Eds), Children's play and learning (pp. 43-56). New York: Teachers College Press. 
Eisner, E. (2002). The educational imagination: On the design and evaluation of school programs. New Jersey: Prentice Hall.

Foddy, W. (1993).Constructing questions for interviews and questionnaires: Theory and practice in social research. London: Cambridge University Press.

Fontana, A. \& Frey, J. (2000). Collecting and interpreting qualitative materials. In N. Denzin and Y. Lincoln. (Eds). Interviewing: The art of science. Sage, Thousand Oaks, C.A., pp.47-78.

Garvis, S. (2010). An investigation of beginning teacher selfefficacy for the arts in the middle years of schooling (Years 4-9). PhD Thesis. University of Queensland, Brisbane.

Garvis, S. \& Pendergast, D. (2010). Middle Years Teachers' Past Experiences of the Arts: Implications for Teacher Education. Australian Journal of Music Education, 2 (Dec), 28-40.

Garvis, S. \& Pendergast, D. (2011). An investigation of early childhood teacher self-efficacy beliefs in the teaching of arts education. International Journal of Education \& the Arts, 12(9). Retrieved 2 November 2011 from http://www.ijea.org/ v12n9/.

Gubrium, J. F. \& Holstein, J. A. (Eds.) (2002). Handbook of Interview Research: Context and Method. Thousand Oaks, CA: Sage.

Hatch, J. A. (2002). Doing qualitative research in educational settings. Albany, NY: State University of New York.

Krippendorff, K. (2004). Content Analysis, an Introduction to Its Methodology, 2nd Edition. Thousand Oaks, CA: Sage.

McArdle, F. (2001). Art in early childhood: The discourse of 'proper' teaching. Unpublished doctoral dissertation, Queensland University of Technology, Brisbane.

McArdle, F. \& Wong, K. B. (2010). What young children say about art: A comparative study. Art in Early Childhood Research Journal, 1. Retrieved 3 February 2012 from http:// www.artinearlychildhood.org/artec/index.php?option=com_ journals\&ltemid=57\&task=show\&id $=6$.

Ministerial Council for Education, Early Childhood Development and Youth Affairs. (MCEETYA) (1999). Adelaide Declaration on National Goals for Schooling in the TwentyFirst Century. Retrieved 2 April 2008 from http://www. mceecdya.edu.au/mceecdya/adelaide_declaration_1999_ text,28298.html.

Ministerial Council for Education, Employment, Training and Youth Affairs (2005). National Education and the Arts Statement. Retrieved 22 June 2011 from http://www. mceetya.edu.au/verve/_resources/National_Education_Arts_ Statement.pdf.

OECD (2006). Starting Strong II: Early Childhood Education and Care. Paris, France: Organisation for Economic Development.

Papousek, M. (1996). Intuitive parenting: a hidden source of musical stimulation in infancy. In I. Deliege and J. Sloboda (Eds). Musical Beginnings, pp. 88-112. Oxford: Oxford University Press.

Pramling Samuelsson, I., Aspland Carlsson, M., Olsson, B., Pramling, N. \& Wallerstedt, C. (2009). The art of teaching children the arts: music, dance and poetry with children aged 2-8 years old. International Journal of Early Years Education, $17(2), 119-135$.
Queensland Government. (2008). Toward Q2 Tomorrow's Queensland: Delivering World Class Education-Starting Early. Retrieved 2 June 2011 from http://www.towardq2.qld. gov.au/library/pdf/tomorrow/Education_Starting_early.pdf.

Queensland Government (2011). Kindergarten Programs. Retrieved 3 July 2011 from http://.deta.qld.gov.au/ earlychildhood/families/kindy-programs.html

Richards, R. (2007). Outdated relics on hallowed ground: Unearthing attitudes and beliefs about young children's art. Australian Journal of Early Childhood, 32(4). 22-30.

Rolnick, A. \& Grunewald, R. (2003, March). Early childhood development: Economic development with a high public return. Minnesota Fedgazette.

Russell-Bowie, D. (2009). MMADD about the arts: An introduction to primary arts education. Frenchs Forest, NSW: Pearson Education Australia.

Seidman. I. E. (1991). Interviewing as qualitative research. New York: Teachers College Press.

Shaughnessy, M. F. (2004). An interview with Anita Woolfolk: The educational psychology of teacher efficacy. Educational Psychology, 16(2). 153-176.

Shonkoff, J. P. \& Phillips, D. A. (Eds) (2000). From Neurons to Neighbourhoods: The Science of Early Childhood Development, Washington, DC: National Academy Press.

Trevarthen, C. (2002). Origins of musical identity: evidence from infancy for musical social awareness. In R. A. R. MacDonald, D. J. Hargreaves and D. Miell (Eds), Musical Identities, pp. 21-38. Oxford: Oxford University Press.

Trevarthen, C. \& Malloch, S. (2000) The dance of well-being: defining the musical therapeutic effect. The Nordic Journal of Music Therapy, 9(2), 3-17.

United Nations Educational, Scientific and Cultural Organisation (UNESCO) Italy (2006). Road map for arts education. Retrieved 3 April 2008 from http://portal.unesco. org/culture/en/ev.php-URL_ID=30335\&URL_DO=DO_ TOPIC\&URL_SECTION=201.html.

Vimpani, G. (2005). The case for national investment in early childhood, The New Matilda, Vol. 64, Retrieved 26 June 2011 from www.newmatilda.com/policytoolkit/policydetail. asp?policylD.

Wallen, N. \& Fraenkel, J. (2001). Educational research: A guide to the process (2nd edn). Mahwah, New Jersey: Lawrence Erlbaum.

Wright, S. (2003a). Ways of knowing in the arts. In S. Wright (Ed.), Children, meaning-making and the arts (pp. 1-34). Frenchs Forest, NSW: Pearson Education Australia.

Wright, S. (2003b). The arts, young children and learning. Boston, MA: Allyn and Bacon.

Wright, S. (2007). Young children's meaning making through drawing and 'telling': Analogies to filmic textual features. Australasian Journal of Early Childhood, 32(4), 37-48. 